a normal cerebrospinal fluid examination. Severe $C$ jejuni infections have been reported in patients with immunodeficiency, ${ }^{5}$ such as HIV infection. ${ }^{6}$ Only one case of $C$ jejuni septicaemia occuring in a post-splenectomy patient has been reported previously, and that patient was also an iron overloaded thalassaemic with chronic liver disease who also had diabetes mellitus. ${ }^{7}$ There appears to be no obvious reason why $C$ jejuni would show a predilection for growth in such patients, unlike Yersinia spp which grows more readily in iron overloaded patients. ${ }^{8}$ Septicaemic shock is thought to occur in severe $C$ jejuni infections because of the bacteria's lipopolysaccharide content, ${ }^{9}$ and perhaps because of the secretion of an enterotoxin. ${ }^{10}$

Thalassaemia is a common indication for splenectomy, and these patients may be immunocompromised in other ways, for example by the effects of multiple blood transfusions, viral infection, iron overload, or diabetes mellitus. In addition, the presence of chronic liver disease and impaired cardiac function in this patient would have impaired his ability to counter the infection and withstand its effects. Our patient was given gentamicin (to which the organism was sensitive) from the time of admission, but he still died owing to a combination of septicaemic shock and hepatic encephalopathy. Although the dose of gentamicin was as recommended ( $5 \mathrm{mg} / \mathrm{kg} /$ day), no loading dose was given and the post-dose serum concentra- tion was subtherapeutic. These factors may also have contributed to the poor clinical response. The possibility of a campylobacter septicaemia should be considered when a splenectomised thalassaemia patient presents with high grade fever, and appropriate high dose antibiotic coverage should be instituted.

1 Anon. Splenectomy-a long-term risk of infection [editorial]. Lancet 1985;ii:928-9.

2 Working Party of the British Committee for Standards in Haematology Clinical Haematology Task Force. Guidelines for the prevention and treatment of infection in patients with an absent or dysfunctional spleen. BMF 1996;312:430-4.

3 Karmali MA, Skirrow MB. Taxonomy of the genus Campylobacter. In: Butzler JP, ed. Campylobacter infection in man and animals. Boca Raton: CRC Press; 1984:1--20.

4 Spelman DW, Davidson N, Buckmaster ND, Spicer WJ, Ryan P. Campylobacter bacteraemia: a report of 10 cases. Med F Aust 1986;145:503-5.

5 Blaser MJ, Perez-Perez G, Smith PF, Patton C, Tenover FC, Lastovica AJ, et al. Extraintestinal Campylobacter jejuni and Campylobacter coli infections: host factors and strain characteristics. F Infect Dis 1986;153:552-9.

6 Perlman DM, Ampel NM, Schifman RB, Cohn DL, Patton $\mathrm{CM}$, Aguirre ML, et al. Persistent Campylobacter jejuni infections in patients infected with human immunodeficiency virus (HIV). Ann Intern Med 1988;108:540-6.

7 Meyrieux V, Monneret G, Lepape A, Chomarat M, Banssillon V. Fatal septic shock with multiple organ failure due to Campylobacter jejuni. Clin Infect Dis 1996;22:183-4.

8 Robins-Browne RN, Robson AR, Koornkof HJ. Generalised infection with Yersinia enterocolitica and the role of iron. Contrib Microbiol Immunol 1979;5:277-82.

9 Mills SD, Aspinall GO, McDonald AG, Raju TS, Kurjanczyk LA, Penner JL. Lipopolysaccharide antigens of Campylobacter jejuni. In: Nachamkin I, Blaser MJ, Tompkins LS, eds. Campylobacter jejuni: Current status and future trends. Washington, DC: American Society for Microbiology; 1992:223-9.

10 Van Der Zwann JC. Toxic shock syndrome caused by Campylobacter intestinalis [letter]. Lancet 1984;i:449.
Department of Microbiology, All India Institute of Medical Sciences, Ansari Nagar, New Delhi-110 029, India

Correspondence to: Dr Rama Chaudhry.

Accepted for publication 22 January 1997

\section{Standardisation of polymerase chain reaction for the detection of Salmonella typhi in typhoid fever}

\author{
Rama Chaudhry, B V Laxmi, Nazima Nisar, Koninika Ray, Dinesh Kumar
}

pected cases were positive by PCR; four of which were culture negative. No amplification was seen in samples from patients who were culture positive for organisms other than $S$ typhi or from controls. The time taken for each sample for PCR analysis was less than 48 hours compared with three to five days for blood or clot culture. PCR appeared to be a promising diagnostic test for typhoid fever.

(f Clin Pathol 1997;50:437-439)

Keywords: Salmonella typhi; polymerase chain reaction; typhoid fever

Typhoid fever, a septicaemic disease caused by Salmonella typhi, is a serious health problem in developing countries. ${ }^{\prime 2}$ Diagnosis of typhoid fever currently relies on blood culture and Widal's test. Blood cultures are negative in $30-65 \%$ of cases with typhoid fever because of 
Table 1 Bacterial strains used to develop a PCR assay for the diagnosis of typhoid fever

\begin{tabular}{|c|c|c|}
\hline Species & Flagellar type & Sources \\
\hline $\begin{array}{l}\text { Salmonella strains } \\
\text { S typhi }(6) \\
\text { S livingstone } \\
S \text { stanlay } \\
S \text { schwarzangrund } \\
S \text { paratyphi } \mathrm{A} \\
S \text { paratyphi } \mathrm{B} \\
S \text { paratyphi } \mathrm{C} \\
\text { S typhimurium } \\
S \text { cholerasuis } \\
\text { S enteritidis } \\
S \text { senftenberg }(\mathrm{JT} 1502)\end{array}$ & $\begin{array}{l}\text { d } \\
\text { d, i, w } \\
\text { d, i, z } \\
\text { d } \\
\text { a } \\
\text { b } \\
\text { c } \\
\text { i } \\
\text { c } \\
\text { g, m } \\
\text { I, s, t }\end{array}$ & $\begin{array}{l}\text { AIIMS } \\
\text { CRI, Kasauli } \\
\text { CRI, Kasauli } \\
\text { CRI, Kasauli } \\
\text { AIIMS } \\
\text { CRI, Kasauli } \\
\text { CRI, Kasauli } \\
\text { CRI, Kasauli } \\
\text { CRI, Kasauli } \\
\text { CRI, Kasauli } \\
\text { CRI, Kasauli }\end{array}$ \\
\hline $\begin{array}{l}\text { Non-salmonella strains } \\
\text { Escherichia coli } \\
\text { Klebsiella pneumoniae } \\
\text { Klebsiella spp } \\
\text { Staphylococcus aureus } \\
\text { Pseudomonas aeruginosa } \\
\text { Enterobacter spp } \\
\text { Bacteriodes melaninogenicus } \\
\text { Clostridium perfringens } \\
\text { Acinetobacter spp } \\
\text { Diphtheroids }\end{array}$ & & $\begin{array}{l}\text { AIIMS } \\
\text { AIIMS } \\
\text { AIIMS } \\
\text { AIIMS } \\
\text { AIIMS } \\
\text { AIIMS } \\
\text { AIIMS } \\
\text { AIIMS } \\
\text { AIIMS } \\
\text { AIIMS }\end{array}$ \\
\hline
\end{tabular}

AIIMS, All India Institute of Medical Sciences; CRI, Central Research Institute.

prior administration of antibiotics or a low number of organisms. ${ }^{3-5}$ Negative blood culture reports in patients with typhoid fever underestimates the actual incidence of disease. Widal's test has been found to be non-specific and difficult to interpret in areas where typhoid fever is endemic. ${ }^{67}$ No non-cultural test for typhoid fever has been consistently shown to be sufficiently sensitive and specific. ${ }^{1}$ There is, therefore, a need to develop a highly sensitive and specific method for the diagnosis of patients with negative blood cultures. We report the development and evaluation of a polymerase chain reaction (PCR) assay to detect $S$ typhi from peripheral blood of patients with typhoid fever by amplification of $\mathrm{dH}$ flagellin gene.

\section{Methods}

Six $S$ typhi strains and 10 non-salmonella strains were grown overnight in Luria broth (table 1) and tested to study the specificity of the PCR assay. $S 901$ (motile), a standard strain of $S$ typhi was used as positive control. The

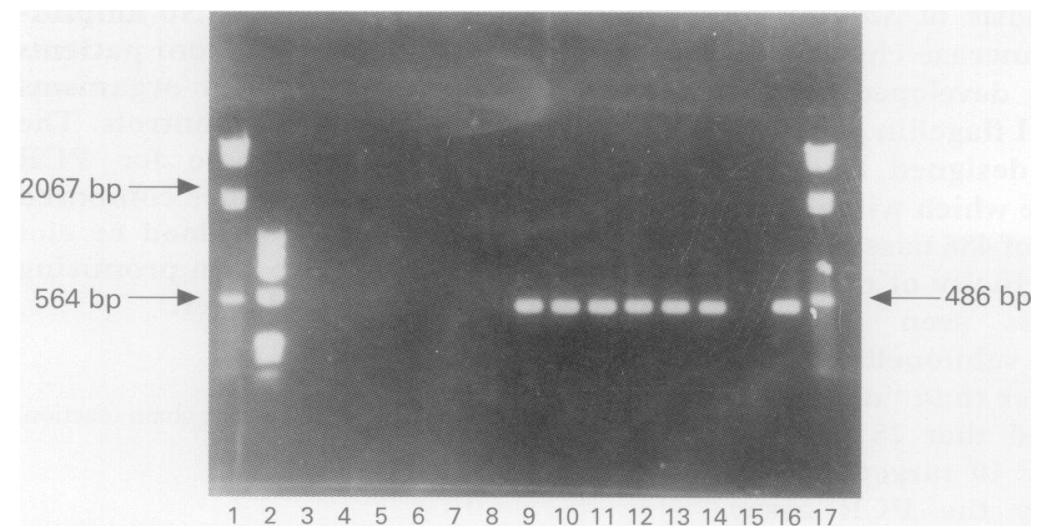

Figure 1 Specificity of the PCR assay for the detection of the flagellin gene of $\mathrm{S}$ typhi. Lane 1 and 17, Hind III digest marker; Lane 2, X174 marker; Lane 3, Escherichia coli, Lane 4, Staphylococcus aureus; Lane 5, Pseudomonas aeruginosa; Lane 6, Salmonella paratyphi $A$; Lane 7; acinetobacter; Lane 8, S paratyphi $B$; Lane 9, S typhi I; Lane 10, S typhi II; Lane 11, S typhi III; Lane 12, S typhi IV; Lane 13, S typhi I (DNA extracted 10 days previously); Lane 14, S typhi II (DNA extracted 10 days previously); Lane 15, water (no DNA); Lane 16, S typhi $S 901$ (mobile) reference strain. primers were designed based on published $\mathrm{dH}$ flagellin gene sequence ${ }^{2}$ using Oligo Computer Program. To investigate the sensitivity of the system, overnight culture of S901 was titrated by counting colonies on nutrient agar plates after 10 -fold serial dilution of organisms ranging from $10^{6}$ to $10^{1}$; DNA extracted from $S$ typhi was serially diluted to determine the minimum amount of DNA detectable by PCR.

Blood samples were collected from 84 patients with clinically suspected typhoid fever attending our institution as well as from 20 normal healthy individuals to be used as negative controls. Serum was removed from $5 \mathrm{ml}$ of blood collected in a sterile tube. The clot was then added to $5 \mathrm{ml}$ of $10 \%$ bile broth. Clots were broken by vortexing with sterile glass beads for five minutes and incubated overnight at $37^{\circ} \mathrm{C}$. The following morning DNA was extracted by boiling method. ${ }^{8}$ For 36 samples, DNA was extracted from citrated blood by lysis method using Proteinase $\mathrm{K}$ and Triton X-100. ${ }^{9}$ The target for amplification was the $\mathrm{dH}$ flagellin gene. A 486 base pair region was amplified with specific primers RK1 (5' TGG GCG ACG ATT TCT ATG CC 3') and RK2 (5' TTT CGC GAA CCT GGT TAG CC $3^{\prime}$ ). Amplification was carried out with $50 \mathrm{pmol}$ of each primer in $25 \mu \mathrm{l}$ of the PCR solution containing 0.625 units of Taq DNA polymerase, $2.5 \mathrm{mM} \mathrm{MgCl}, 200 \mu \mathrm{m}$ each of dATP, dCTP, dTTP, dGTP, and $1 \times$ PCR buffer (Perkin Elmer, Rotkreuz, Switzerland). The reactions were performed in a DNA thermocycler (MJ Research Inc, Massachusetts, USA) as follows: 40 cycles of denaturation at $94^{\circ} \mathrm{C}$ for one minute, annealing at $57^{\circ} \mathrm{C}$ for one minute 15 seconds, elongation at $72^{\circ} \mathrm{C}$ for three minutes, and final extension of five minutes at $72^{\circ} \mathrm{C}$. PCR products were visualised on a $1.2 \%$ agarose gel stained with ethidium bromide.

\section{Results}

PCR with RK1 and RK2 primers was found to be specific for $\mathrm{dH}$ flagellin gene, amplifying the $S$ typhi specific band of 486 base pairs. No amplification was seen in any non-salmonella strain or the other seven Salmonella spp with flagellar gene other than " $d$ ", or in DNA extracted from humans (fig 1). We also investigated other Salmonella spp containing $\mathrm{dH}$ flagellin gene- $S$ stanley, $S$ livingstone, and $S$ Schwarzangrund - and amplification of the 486 base pair segment was seen.

The minimum number of organisms detected by PCR was $3 \times 10^{2}$. The amount of DNA which could be detected after serial dilution was $28 \mathrm{pg}$ (fig 2).

Of 84 patients with clinically suspected typhoid fever, 21 were both culture and PCR positive for $S$ typhi. Four additional cases were. positive by PCR but culture negative after 48 hours (table 2). No amplification was seen in patients that were culture positive for organisms other than $S$ typhi or in controls

\section{Discussion}

Isolation of $S$ typhi from blood is the most satisfactory method of diagnosis in the early stage of typhoid fever as bacteraemia is present dur- 


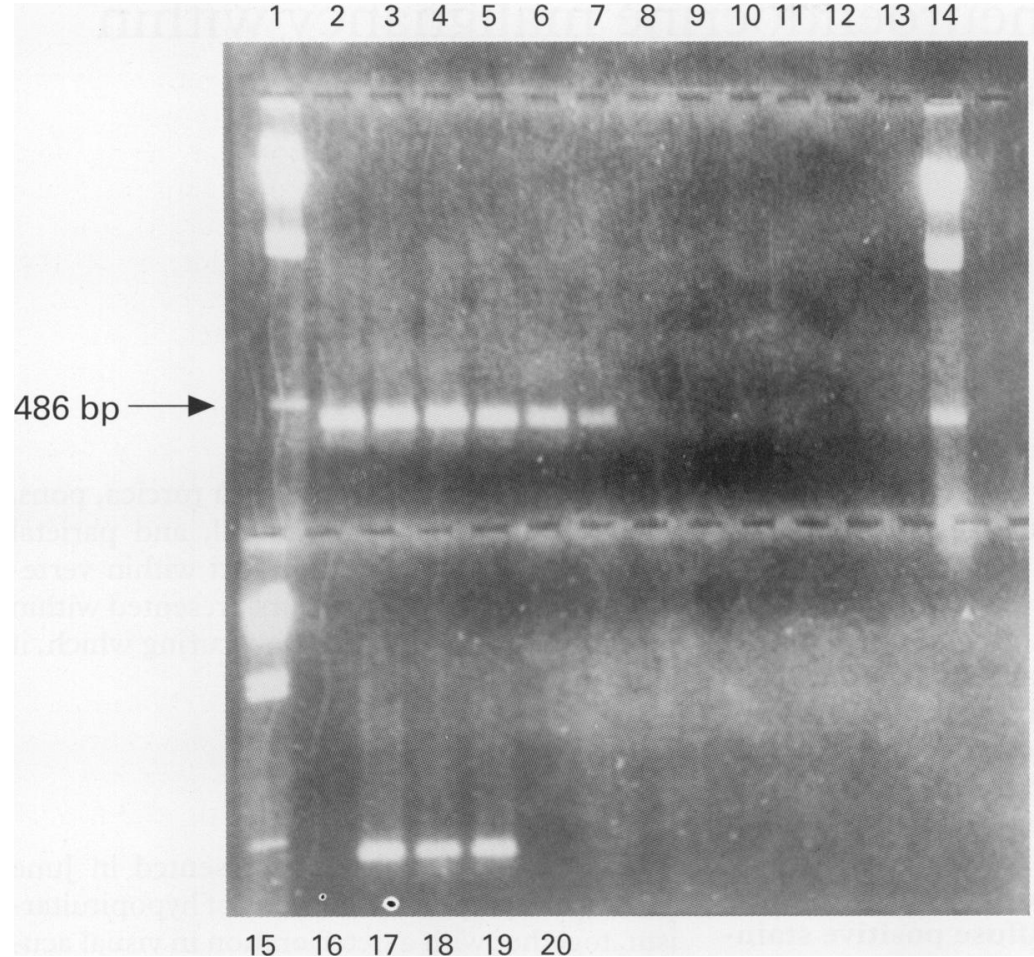

Figure 2 Sensitivity of the PCR assay with serially diluted DNA from $S$ typhi S901. Lanes 1, 14, and 15, marker; Lane 2, $2800 \mathrm{ng}$; Lane 3, $280 \mathrm{ng}$; Lane 4, $28 \mathrm{ng}$; Lane 5, $2.8 \mathrm{ng}$; Lane 6, 280 pg; Lane 7, 28 pg; Lane 8, 2.8 pg; Lane 9, $280 \mathrm{fg}$; Lane 10, $28 \mathrm{fg}$; Lane 11, 2.8 fg; Lane 12, negative control (distilled water); Lane 13, S typhi with no enzyme; Lane 16, Human DNA; Lane 17, S typhi $\$ 901$ (mobile) reference strain; Lane 18, S typhi I; Lane 19, S typhi II; Lane 20, PCR mix only.

ing the first week of illness. Negative blood culture results, because of low concentrations of bacteraemia or previous antibiotic treatment, ${ }^{38}$ in suspected cases of typhoid fever may lead to misdiagnosis and improper treatment. Sensitivity can be increased if clinical specimens can be obtained for culture from bone marrow; however, this is an invasive technique and it is not amenable to routine use in patients with typhoid fever. Blood culture is widely practised because of its simplicity, safety, and noninvasiveness. PCR, a highly sensitive method to detect very low quantities of infectious organisms shows promise for typhoid fever diagnosis. Compared with the study by Song et al, ${ }^{10}$ sensitivity of our PCR using RK1 and RK2 primers was very high ( $28 \mathrm{pg}$ versus $4 \mathrm{ng}$ by one round of PCR). We could detect as few as 300 bacteria by a single round of PCR compared with $10^{6}$ bacteria by Song et al.

Table 2 Results of culture and PCR assay

\begin{tabular}{llll}
\hline \multicolumn{4}{l}{ Blood/clot culture } \\
\cline { 2 - 4 } & Positive & Negative & Total \\
\hline PCR positive & 21 & 4 & 25 \\
PCR negative & 0 & 59 & 59 \\
Total & 21 & 63 & 84 \\
\hline
\end{tabular}

Other Salmonella spp containing $\mathrm{dH}$ flagellin do not infect humans. In addition, these primers were designed to amplify a region of $S$ typh $i$ that is not affected by the deletion mutation reported by Song et al. ${ }^{11}$ Therefore, it seems to be a more promising diagnostic approach compared with the conventional procedure of culturing and identifying $S$ typhi strains with $\mathrm{dH}$ antisera that may miss $S$ typhi strains with mutated flagellin gene, that is, $\mathrm{jH}$ rather than $\mathrm{dH}$.

The specificity of PCR was $93.7 \%$ and sensitivity was $100 \%$. The predictive positive value was $84 \%$ and predictive negative value was $100 \%$. Four culture false positive cases were actually additional cases of typhoid fever detected by PCR. There were no false negative cases.

PCR detection of $S$ typhi took less than 48 hours, compared with five to seven days for blood or clot culture. Therefore, PCR was a rapid, sensitive, and specific test for the diagnosis of typhoid fever, especially where blood culture was negative because of prior antibiotic treatment, low level of bacteraemia, and culture done in late stages of disease, thus enabling the clinician to use appropriate treatment and to avoid diagnostic delay.

We gratefully acknowledge the help of Dr SK Panda, Department of Pathology, with synthesis of the primers. We also acknowledge Drs B Das, L Ming, and Jaya Tyagi, Departmen of Biotechnology, Dr AB Dey, Department of Medicine, and D Sundram, Department of Biostatistics, All India Institute of Medical Sciences. The technical assistance of Mr Salek Chand, Mr Pooran Arya, and Mr Ramesh Yadav is also acknowledged. Financial assistance from the department of biotechnology, New Delhi (project no. BT/R+D/9/11/94) is acknowledged.

1 Edelman R, Levine MM. Summary of an international workshop on typhoid fever. Rev Infect Dis 1986;8:329-49.

2 Frankel G, Newton SMC, Schoolnik GK, Stocker BAI. Unique sequences in region VI of the flagellin gene of Salmonella typhi. Mol Microbiol 1989;3:1379-83.

3 Gilman RH, Terminel M, Levine MM, Hernandez-Mendoz P, Hornick RB. Relative efficacy of blood, urine, rectal swab, bone marrow and rose spot cultures for recovery of swab, bone marrow and rose spot cultures for recovery of Guerra-caceras JG, Gotuzzo-Herencia E, Crosby-Dagnino E, Miro-quesada J, Carillo-Parodi C. Diagnostic value of bone marrow culture in typhoid fever. Trans $R$ Soc Trop Med Hyg 1979;73:680-3.

5 Hoffman SL, Edman DC, Punjabi NH, Lesmana M, Chol A, Sundah S, et al. Bone marrow aspirate culture superio

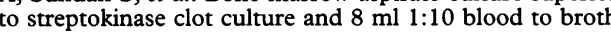
culture for diagnosis of typhoid fever. Am $\mathcal{F}$ Trop Med Hyg 1986;35:836-9.

6 Levine MM, Grados O, Gilman RH, Woodward ME, SolisPlaza R, Waldman W. Diagnostic value of Widal test in areas endemic for typhoid fever. Am F Trop Med Hyg 1978; 27:795-800.

7 Pang T, Puthncheary S. Significance and value of widal test in the diagnosis of typhoid fever in an endemic area. 7 Clin Pathol 1983;36:471-5.

8 Saiki RK. In: Innis MA, ed. PCR protocol. San Diego, Academic Press Inc, 1990:13.

9 Joshi AR, Sinha S, Dil-Afrose, Sulaiman IM, Banerjee AK, Hasnain SE. Alterations in brain tumour DNA located by a fingerprinting probe. Ind $\mathcal{F}$ Biophys Biochem 1996;33:455-7.

10 Song JH, Cho H, Park MY, Na DS, Moon HB, Pai CH Detection of Salmonella typhi in the blood of patients with typhoid fever by polymerase chain reaction. $\mathcal{F}$ Clin Microbio 1993;31:1439-43.

11 Song JH, Cho H, Park MY, Kim YS, Moon HB, Pai CH Detection of the Hi-j strain of Salmonella typhi among Korean isolates by polymerase chain reaction. Am ₹ Trop Med Hyg 1994;50:608-11. 